\title{
Overexpression of Human Low Density Lipoprotein Receptors Leads to Accelerated Catabolism of Lp(a) Lipoprotein in Transgenic Mice
}

\author{
Sandra L. Hofmann, ${ }^{*}$ Dan L. Eaton, ${ }^{\ddagger}$ Michael S. Brown, ${ }^{\star}$ Walter J. McConathy, Joseph L. Goldstein, ${ }^{*}$ and Robert E. Hammeri" \\ Departments of *Molecular Genetics, ${ }^{*}$ Internal Medicine, and "Cell Biology, and 'Howard Hughes Medical Institute, University of \\ Texas Southwestern Medical Center, Dallas, Texas 75235; ${ }^{\ddagger}$ Department of Cardiovascular Research, Genentech, Inc., South San \\ Francisco, California 94080; and ${ }^{\S}$ Oklahoma Medical Research Foundation, Oklahoma City, Oklahoma 73104
}

\begin{abstract}
Lp(a) lipoprotein purified from human plasma bound with high affinity to isolated bovine LDL receptors on nitrocellulose blots and in a solid-phase assay. $L p(a)$ also competed with ${ }^{125}$ I-LDL for binding to human LDL receptors in intact fibroblasts. Binding led to cellular uptake of $L p(a)$ with subsequent stimulation of cholesterol esterification. After intravenous injection, human $\mathrm{Lp}(\mathrm{a})$ was cleared slowly from the plasma of normal mice. The clearance was markedly accelerated in transgenic mice that expressed large amounts of LDL receptors. We conclude that the covalent attachment of apo(a) to apo B-100 in $L p(a)$ does not interfere markedly with the ability of apo B-100 to bind to the LDL receptor and that this receptor has the potential to play a major role in clearance of $L p(a)$ from the circulation of intact humans. (J. Clin. Invest. 1990. 85:1542-1547.) Lp(a) lipoprotein • cholesterol metabolism • LDL receptors • thrombosis • transgenic mice
\end{abstract}

\section{Introduction}

Lp(a), a lipoprotein particle found in the plasma of higher primates and many humans, is an important predisposing factor to atherosclerosis (reviewed in reference 1). The major component of $\mathrm{Lp}(\mathrm{a})$ is a LDL particle, which contains a single protein of $\sim 550 \mathrm{kD}$, designated apoprotein (apo) ${ }^{1}$ B-100. $\mathrm{Lp}$ (a) differs from LDL in containing an additional protein, designated apo(a), that is attached to apo B-100 in disulfide linkage. Apo(a) is related structurally to plasminogen, a circulating serine protease that is activated during clot lysis $(2,3)$. Plasminogen, like several other proteases of the blood clotting system, contains several cysteine-rich sequences called kringles. Apo(a) contains 37 or more copies of one particular kringle, namely kringle 4 , followed by a single copy of kringle 5 and a protease domain (2). At least six different alleles exist at the apo(a) locus in humans, and these produce apo(a) proteins that vary in molecular weight from $\sim 400,000$ to 700,000 (4). This size variation is apparently attributable to different num-

Received for publication 21 November 1989.

1. Abbreviations used in this paper: apo, apoprotein; FH, familial hypercholesterolemia; IDL, intermediate density lipoprotein.

J. Clin. Invest.

(c) The American Society for Clinical Investigation, Inc.

$0021-9738 / 90 / 05 / 1542 / 06 \$ 2.00$

Volume 85, May 1990, 1542-1547 bers of copies of kringle 4 (1). There are also apparent null alleles that produce no detectable circulating protein (1).

In Caucasian populations, the distribution of $\mathrm{Lp}(\mathrm{a})$ concentrations in plasma is highly skewed. Most subjects have $\mathrm{Lp}$ (a) concentrations below $30 \mathrm{mg} / \mathrm{dl}$, but a substantial minority have concentrations extending up to $100 \mathrm{mg} / \mathrm{dl}(1)$. The latter individuals are at greatly increased risk for coronary artery disease. Part of the variation in $L p(a)$ concentrations is attributable to the allele at the apo(a) locus. In general, the smaller apo(a) proteins are present at higher levels in plasma.

Substantial variability in Lp(a) levels exists even among individuals who produce the same size apo(a) protein. One reason for this variation relates to allelic differences at the LDL receptor locus. Individuals with familial hypercholesterolemia (FH), who have one defective LDL receptor gene, have a twoto three-fold elevation in plasma $\mathrm{Lp}(\mathrm{a})$ levels when compared with other individuals who have the same genotype at the apo(a) locus (5). These findings suggest that $L p(a)$, like $L D L$, is removed from plasma by binding to LDL receptors.

Several studies of $\mathrm{Lp}(\mathrm{a})$ binding and metabolism in cultured human fibroblasts have suggested that the lipoprotein binds to LDL receptors, but conflicting data have appeared. Maartmann-Moe and Berg (6) originally presented evidence that $\mathrm{Lp}(\mathrm{a})$ bound poorly, if at all, to LDL receptors. Floren et al. (7), in contrast, showed that $\mathrm{Lp}(\mathrm{a})$ stimulated the synthesis of cholesteryl esters in normal human fibroblasts, an event that requires receptor-mediated endocytosis of the lipoprotein. Lp(a) had much less effect on fibroblasts from a patient with homozygous $\mathrm{FH}$, strongly suggesting that LDL receptors were involved. Havekes et al. (8) also provided evidence that $L p(a)$ binds to LDL receptors in human fibroblasts. Armstrong et al. (9), on the other hand, found that $\operatorname{Lp}(a)$ was not taken up as readily as LDL in fibroblasts and that uptake of the lipoprotein was markedly increased when the disulfide bond was reduced, liberating apo(a) and generating active LDL. In the most comprehensive study to date, Krempler et al. (10) showed that

${ }^{125}$ I-labeled $\mathrm{Lp}(\mathrm{a})$ bound to fibroblasts with an affinity that was comparable to that of LDL and that the two lipoproteins showed cross competition. These investigators also showed that the fractional catabolic rate of intravenously-administered $\mathrm{Lp}(\mathrm{a})$ was correlated with the fractional catabolic rate of $\mathrm{LDL}$ in intact human subjects.

With the availability of purified LDL receptors (11), it is now possible to study the receptor binding of lipoproteins directly. In the current studies, we show that $\mathrm{Lp}(\mathrm{a})$ binds to purified LDL receptors in vitro with an affinity similar to that of LDL. We also show that the clearance of human $\mathrm{Lp}(\mathrm{a})$ from plasma is markedly elevated in transgenic mice that overproduce human LDL receptors (12). These data provide strong support for the hypothesis that the LDL receptor plays an important role in the catabolism of $\mathrm{Lp}(\mathrm{a})$. 


\section{Methods}

Materials. We obtained bovine serum albumin (fraction V., No. A4503) from Sigma Chemical Co. (St. Louis, MO); low molecular weight markers from Bio-Rad Laboratories (Richmond, CA); high molecular weight markers from Pharmacia Fine Chemicals (Piscataway, NJ); nitrocellulose (BA85) from Schleicher and Schuell, Inc. (Keene, NH); and rabbit anti-human LDL IgG from CalbiochemBehring Corp. (San Diego, CA). Goat anti-rabbit IgG and rabbit antimouse IgG were obtained from Cappell Laboratories (Malvern, PA) and radiolabeled with ${ }^{125} I$ as described (13). Bovine LDL receptor was purified as described (11). Normal mice $($ C57BL $\times$ SJL) were obtained from Jackson Laboratory (Bar Harbor, ME). Homozygous transgenic mice were derived from a previously described strain of mice expressing the human LDL receptor cDNA transgene under the control of the mouse metallothionein-I promoter (line 93-4) (12).

Preparation of lipoproteins. Human LDL $(d 1.019-1.063 \mathrm{~g} / \mathrm{ml})$ was prepared from the plasma of healthy subjects by $\mathrm{KBr}$ density gradient ultracentrifugation as described (14). LDL was radioiodinated with ${ }^{125}$ I by the iodine monochloride method (14). Lp(a) was prepared by two different methods. $\mathrm{Lp}(\mathrm{a})$ was isolated from subjects 1 and 2 by ultracentrifugation $(d 1.050-1.120 \mathrm{~g} / \mathrm{ml})$ followed by Sepharose CL-6B chromatography as described by Ye et al. (15). The fractions containing $L p(a)$ had pre- $\beta$ mobility on agarose electrophoresis, reacted with anti-Lp(a) and anti-LDL antisera by Ouchterlony double diffusion analysis, and had no contamination with other apo B-containing lipoproteins as shown by double-tier rocket immunoelectrophoresis (15). Lp(a) from subjects 3,4 , and 5 was prepared by ultracentrifugation and monoclonal antibody affinity chromatography, employing a monoclonal antibody specific for apo(a). Briefly, plasma from subjects with high $\mathrm{Lp}(\mathrm{a})$ levels was adjusted to $1 \mathrm{mM}$ each of diisopropylfluorophosphate, EDTA, and sodium azide, and to a density of $1.21 \mathrm{~g} / \mathrm{ml}$ by the addition of solid $\mathrm{NaBr}$. The plasma was centrifuged at $59,000 \mathrm{rpm}$ for $20 \mathrm{~h}$ at $19^{\circ} \mathrm{C}$ in a $60 \mathrm{Ti}$ rotor (Beckman Instruments, Inc., Palo Alto, CA), and the floating lipoprotein fraction was collected and immediately passed over an Lp(a) monoclonal antibody column (monoclonal 2G7, coupled to glycerol-coated control pore glass [16]). The column was washed with buffer containing $50 \mathrm{mM}$ Tris- $\mathrm{HCl}$ at $\mathrm{pH} 7.5$, $1 \mathrm{M} \mathrm{NaCl}, 1 \mathrm{mM}$ diisopropylfluorophosphate, $1 \mathrm{mM}$ EDTA, and 1 $\mathrm{mM}$ sodium azide, after which the $\mathrm{Lp}(\mathrm{a})$ was eluted with $0.1 \mathrm{M}$ glycine- $\mathrm{HCl}$ ethyl ester at $\mathrm{pH}$ 2.3. Eluted fractions were neutralized by collection into 0.1 vol of $1 \mathrm{M}$ Tris- $\mathrm{HCl}, \mathrm{pH} 7.5$. The molecular weights $\left(\times 10^{-3}\right)$ of apo(a) from subjects 1-5, as estimated by SDS-PAGE, were $600,600,480,710$, and 770 , respectively.

Plasma Lp(a) immunoassay. Apo(a)-specific monoclonal antibody 2G7 (16) was bound to microtiter plates by incubation overnight at $4^{\circ} \mathrm{C}$ with $0.1 \mathrm{ml}$ of $0.8 \mu \mathrm{g} / \mathrm{ml}$ of monoclonal antibody per well in 15 $\mathrm{mM} \mathrm{Na} \mathrm{CO}_{3} / 35 \mathrm{mM} \mathrm{NaHCO}$ at $\mathrm{pH} 9.6$. The coating solution was removed and $0.15 \mathrm{ml}$ of $0.5 \%$ (wt/vol) bovine serum albumin in phosphate-buffered saline was added and incubated $1 \mathrm{~h}$ at room temperature. The wells were washed three times with cold phosphate-buffered saline containing $0.05 \%$ (vol/vol) Tween 20 and $0.01 \%$ (wt/vol) thimerosal at pH 7.4 (wash buffer). An Lp(a) standard was prepared by diluting a stock solution into phosphate-buffered saline containing $0.5 \%$ bovine serum albumin, $0.05 \%$ Tween 20 , and $0.01 \%$ thimerosal at pH 7.4 (assay buffer) to give concentrations between 0.5 and $90 \mathrm{ng}$ total protein/ml of $\mathrm{Lp}(\mathrm{a})$. Test samples were diluted in assay buffer. Samples were dispensed into the coated wells $(100 \mu \mathrm{l} /$ well $)$ in duplicate. The microtiter plates were sealed and incubated at room temperature for $3 \mathrm{~h}$ with gentle agitation. The plates were washed six times with wash buffer, after which horseradish peroxidase-labeled antibody (100 $\mu \mathrm{l} /$ well) was added and incubated $2 \mathrm{~h}$ at room temperature (16).

LDL receptor assays in cell monolayers. TR-715-19 cells, a stable line of Chinese hamster ovary cells transfected with a cDNA encoding the human LDL receptor (17) and normal diploid human fibroblasts (14) were grown in monolayer culture as described in the indicated reference. Assays of the cell surface binding of ${ }^{125} \mathrm{I}-\mathrm{LDL}$ at $4^{\circ} \mathrm{C}$ (dextran sulfate-releasable fraction) and of lipoprotein-mediated stimula- tion of cholesteryl $\left[{ }^{14} \mathrm{C}\right]$ oleate formation at $37^{\circ} \mathrm{C}$ were carried out as previously described (14).

LDL receptor ligand blotting assay. Purified bovine LDL receptor $(1 \mu \mathrm{g})(11)$ was subjected to electrophoresis on $7 \%$ SDS polyacrylamide gels under nonreducing conditions and transferred to nitrocellulose filters as previously described (18). The filters were then incubated in a buffer with either human LDL or Lp(a) at a concentration of 5 or $10 \mu \mathrm{g}$ of protein $/ \mathrm{ml}$, respectively, in a buffer containing $50 \mathrm{mM}$ Tris- $\mathrm{HCl}$ at pH $8.0,1 \mathrm{mM}$ potassium iodide, $2 \mathrm{mM} \mathrm{CaCl}$, and $50 \mathrm{mg} / \mathrm{ml}$ bovine serum albumin (blotting buffer). The binding reaction was carried out for $1 \mathrm{~h}$ at $37^{\circ} \mathrm{C}$ with gentle agitation. The filters were washed twice for 15 min with blotting buffer at room temperature, and an IgG fraction of a rabbit anti-human LDL polyclonal antibody or of a mouse monoclonal anti-Lp(a) antibody was added as indicated in the legend to Fig. 2. Incubations were carried out for $1 \mathrm{~h}$ at room temperature. The filters were washed as above, and ${ }^{125}$ I-labeled goat anti-rabbit IgG $\left(5 \times 10^{6}\right.$ $\left.\mathrm{cpm} / \mathrm{ml}, \sim 10^{7} \mathrm{cpm} / \mu \mathrm{g}\right)$ or ${ }^{125}$ I-labeled rabbit anti-mouse IgG $\left(5 \times 10^{6}\right.$ $\mathrm{cpm} / \mathrm{ml}, \sim 10^{7} \mathrm{cpm} / \mu \mathrm{g}$ ) was incubated with the filters for $1 \mathrm{~h}$ at room temperature. The filters were washed, dried, and exposed to film as indicated in the figure legend.

Solid phase LDL binding assay. Binding of ${ }^{125} \mathrm{I}-\mathrm{LDL}$ to the LDL receptor in the presence of unlabeled LDL or Lp(a) was measured using a solid phase assay as described by van Driel et al. (19). Briefly, a monoclonal antibody directed against the $\mathrm{COOH}$-terminal portion of the $\mathrm{LDL}$ receptor $(\mathrm{IgG}-4 \mathrm{~A} 4,0.1 \mathrm{mg} / \mathrm{ml}$ in $50 \mathrm{mM}$ Tris- $\mathrm{HCl}$ at $\mathrm{pH} 8.0$ and $2 \mathrm{mM} \mathrm{CaCl}_{2}$ ) was bound to the welis of a microtiter plate for $1 \mathrm{~h}$ at $37^{\circ} \mathrm{C}$. Unbound antibody was removed, and the wells were incubated in the same buffer containing $1 \%(\mathrm{wt} / \mathrm{vol})$ bovine serum albumin for 1 $\mathrm{h}$ at $37^{\circ} \mathrm{C}$. Purified bovine $\mathrm{LDL}$ receptor $(66 \mathrm{ng})$ was added in a buffer containing $50 \mathrm{~mm}$ Tris- $\mathrm{HCl}$ at $\mathrm{pH} 8.0,2 \mathrm{~mm} \mathrm{CaCl}_{2}$, and $0.5 \%$ bovine serum albumin (buffer A) and incubated for at least $2 \mathrm{~h}$ at $4^{\circ} \mathrm{C}$. Unbound receptor was removed, and the wells were washed three times with buffer $A .{ }^{125} \mathrm{I}-\mathrm{LDL}(5 \mu \mathrm{g}$ protein/ml) and varying concentrations of unlabeled LDL or Lp(a) were mixed in buffer A, added to the wells, and incubated with gentle agitation for $1 \mathrm{~h}$ at $4^{\circ} \mathrm{C}$. The unbound lipoproteins were removed, and the wells were washed four times with buffer $A$ at $4^{\circ} \mathrm{C}$ and counted in a gamma counter. A parallel set of incubations was performed in the presence of $5 \mathrm{mM}$ EDTA, which specifically disrupts the interaction of LDL and its receptor (11). The amount of ${ }^{125} \mathrm{I}-\mathrm{LDL}$ bound in the presence of EDTA was subtracted from that bound in the presence of calcium to determine specific binding.

Clearance of ${ }^{125} I-L D L$ and $L p(a)$ from the plasma of mice. Homozygous transgenic mice that overexpress the human LDL receptor under control of the mouse metallothionein I promoter (12) and normal mice of the same strain ([C57BL $\times$ SJL] F1 hybrids) were treated with $\mathrm{CdSO}_{4}(1 \mathrm{mg} / \mathrm{kg})$ intraperitoneally 12 and $6 \mathrm{~h}$ before the experiment. Approximately equal numbers of male and female animals 4-6 wk of age were used. The mice were anesthetized with sodium pentobarbital ( $90 \mathrm{mg} / \mathrm{kg}$ intraperitoneally), and each received an intravenous bolus via the external jugular vein of $0.15 \mathrm{ml}$ of $0.15 \mathrm{M} \mathrm{NaCl}$ containing bovine serum albumin $(2 \mathrm{mg} / \mathrm{ml}),{ }^{125} \mathrm{I}-\mathrm{LDL}$, and unlabeled $\mathrm{Lp}(\mathrm{a})$, as described in the legend to Fig. 6. In one experiment, an excess of unlabeled LDL $(0.5 \mathrm{mg})$ was co-injected with the ${ }^{125} \mathrm{I}-\mathrm{LDL}$ and Lp(a). Blood was collected by retroorbital puncture and placed in EDTA-coated tubes at the times indicated, and a portion of the plasma was counted for its ${ }^{125}$ I content. The remainder was frozen and assayed at a later time for its Lp(a) content by a monoclonal-based, enzymelinked immunoassay (see above). All transgenic mice had no detectable mouse apo B in the plasma at time 0 ; the average apo $B$ level in the normal mice was $39 \pm 7.4$ (SD) $\mathrm{mg} / \mathrm{dl}$ at time 0 . Apo B levels were determined by rocket immunoelectrophoresis as previously described (12).

\section{Results}

Table I presents the clinical data on the five subjects from whom plasma $\mathrm{Lp}(\mathrm{a})$ was isolated in the current study. The 
Table I. Clinical Data on Subjects from Whom Plasma Lp(a) Was Isolated

\begin{tabular}{cccccc}
\hline Subject & Age & Sex & $\begin{array}{c}\text { Plasma } \\
\text { cholesterol } \\
\text { level }\end{array}$ & $\begin{array}{c}\text { Plasma } \\
\text { Lp(a) level }\end{array}$ & $\begin{array}{c}\text { Predominant } \\
\text { apo(a) isoform }\end{array}$ \\
\hline & & & $m g / d l$ & $m g / d l$ & $m o l w t$ \\
$1^{*}$ & - & - & - & - & 600,000 \\
$2^{*}$ & - & - & - & - & 600,000 \\
3 & 34 & F & 200 & 12 & 480,000 \\
4 & 34 & M & 170 & 16 & 710,000 \\
5 & 48 & F & 260 & 60 & 770,000
\end{tabular}

* Subjects 1 and 2 were anonymous blood donors on whom no clinical data are available.

Lp(a) from subjects 1 and 2 was prepared in Oklahoma, using a gel filtration method (15). $\mathrm{Lp}$ (a) from subjects 3,4 , and 5 was prepared in California, using a monoclonal anti-apo(a) affinity column (16). Fig. 1 shows the protein component of $L p(a)$ from subjects 3,4 , and 5 as visualized by SDS-PAGE. In the absence of reducing agents, all three $\mathrm{Lp}(\mathrm{a})$ preparations gave a single protein band (lanes $D-F$ ). In the presence of dithiothreitol, all three preparations yielded two bands, one corresponding to apo B-100, and the other corresponding to apo(a) (lanes $A-C)$. The apparent molecular mass of the apo(a) bands ranged from $\sim 480 \mathrm{kD}$ in subject 3 to $770 \mathrm{kD}$ in subject 5 . The apparent molecular weights of the apo(a) proteins in $\mathrm{Lp}(\mathrm{a})$ from subjects 1 and 2 were estimated by SDS gel electrophoresis and immunoblotting (not shown).

Fig. 2 shows a ligand blotting experiment designed to test the ability of $\mathrm{Lp}(\mathrm{a})$ to bind to the $\mathrm{LDL}$ receptor. For this purpose, purified bovine LDL receptor was subjected to SDS gel electrophoresis and blotted onto nitrocellulose sheets, which were then incubated with either LDL or Lp(a). After

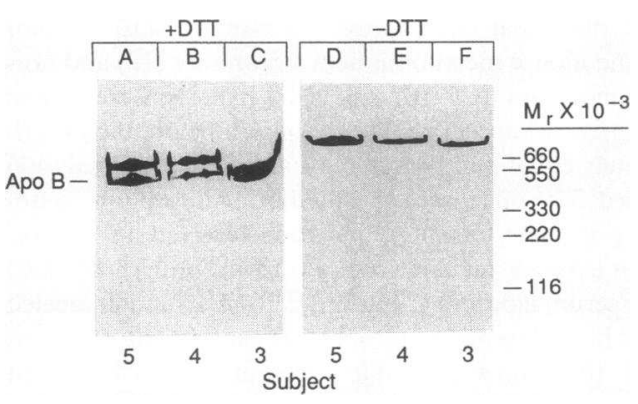

Figure 1. SDS polyacrylamide gel electrophoresis of $\mathrm{Lp}(\mathrm{a})$ from subjects 3-5. SDS gradient gels (2.5-15\%) were prepared according to Laemmli (24). Samples of $\mathrm{Lp}(\mathrm{a})(0.5 \mu \mathrm{g}$ total protein) prepared by monoclonal antibody affinity purification as described under Methods were diluted into sample buffer containing 5\% SDS in the presence $(A-C)$ or absence $(D-F)$ of $10 \mathrm{mM}$ dithiothreitol $(D T T)$ and heated to $95^{\circ} \mathrm{C}$ for 2 min before electrophoresis. Proteins were visualized by staining with silver. The position of migration of the following molecular weight standards run in an adjacent lane is indicated: thyroglobulin dimer, $660 \mathrm{kD}$; apo B-100, $550 \mathrm{kD}$; thyroglobulin monomer, $330 \mathrm{kD}$; myosin, $220 \mathrm{kD}$; and $\beta$-galactosidase, $116 \mathrm{kD}$. The position of migration of the apo B-100 component of $L p(a)$ under reduced conditions is denoted at the left.
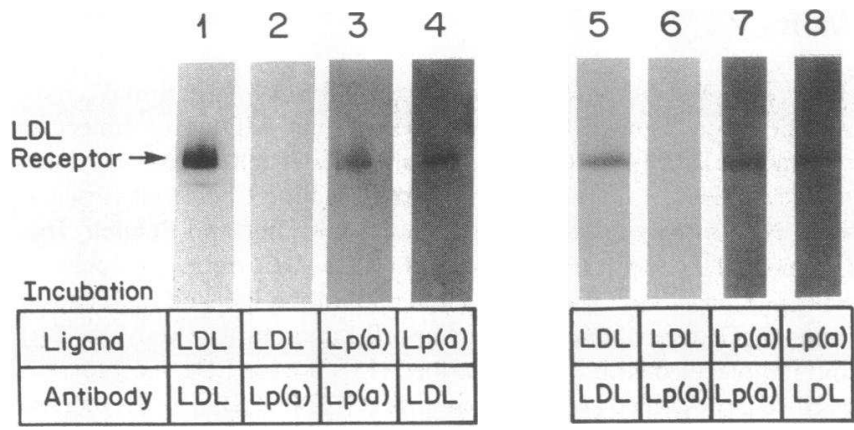

Figure 2. Binding of LDL and Lp(a) to LDL receptors on nitrocellulose filters. Purified bovine LDL receptor $(1 \mu \mathrm{g})$ was subjected to electrophoresis on 7\% SDS slab gels and transferred to nitrocellulose filters as described under Methods. Successive incubations were carried out with human $\operatorname{LDL}(5 \mu \mathrm{g}$ protein $/ \mathrm{ml})$ (lanes $1,2,5$, and 6 ) or human $\mathrm{Lp}(\mathrm{a})(10 \mu \mathrm{g}$ total protein/ml) (lanes $3,4,7$, and 8$)$ followed by rabbit antihuman LDL IgG (lanes $1,4,5$, and 8 ) or mouse monoclonal antihuman $\mathrm{Lp}$ (a) IgG (lanes $2,3,6$, and 7). Bound antibody was visualized with ${ }^{125}$ I-labeled goat anti-rabbit IgG (lanes $1,4,5$, and 8 ) or ${ }^{125}$ I-labeled rabbit anti-mouse IgG (lanes 2, 3, 6, and 7). The dried filters were exposed to Kodak XAR-5 film at room temperature for $2 \mathrm{~h}$ (lanes 1-4) or $30 \mathrm{~min}$ (lanes 5-8). The $\mathrm{Lp}(\mathrm{a})$ used in lanes 3 and 4 was prepared from subject 4 by monoclonal antibody affinity chromatography. The $\mathrm{Lp}(\mathrm{a})$ used in lanes 7 and 8 was prepared from subject 2 by Sepharose CL-6B chromatography as described under Methods.

washing, the sheets were stained with an antibody directed against LDL or with a specific antibody against the apo(a) component of $\mathrm{Lp}(\mathrm{a})$. We used $\mathrm{Lp}(\mathrm{a})$ from two different subjects, number 4 prepared in California (left) and number 2 prepared in Oklahoma (right). Both $\mathrm{Lp}(\mathrm{a})$ preparations gave similar results. When the nitrocellulose sheets were incubated with LDL, a labeled band was observed with the antibody against LDL (lanes 1 and 5), but not with the antibody against Lp(a) (lanes 2 and 6). This finding confirms that the Lp(a) antibody was specific for the apo(a) component of $L p(a)$. When the nitrocellulose sheets were incubated with $\mathrm{Lp}(\mathrm{a})$ and then stained with the $\mathrm{Lp}(\mathrm{a})$ antibody, positive immunoreactivity was seen (lanes 3 and 7). A positive result was also observed when these strips were stained with the anti-LDL antibody (lanes 4 and 8 ). These data indicate that the bovine LDL receptor binds intact $\mathrm{Lp}(\mathrm{a})$.

To determine whether the human LDL receptor recognized $L p(a)$ when present on the surface of intact cells, we measured the ability of unlabeled $\mathrm{Lp}(\mathrm{a})$ to compete with ${ }^{125} \mathrm{I}$ LDL for binding to hamster cells that express high levels of the human LDL receptor, owing to transfection with an expressible cDNA. As shown in Fig. 3, Lp(a) from subjects 1 and 2 was equally as effective as $\mathrm{LDL}$ in competing for ${ }^{125} \mathrm{I}-\mathrm{LDL}$ binding when the data are expressed on the basis of the apo B-100 content of the lipoprotein particle. These findings suggest that the apo B component of these $L p(a)$ preparations bound to the human LDL receptor with an affinity similar to that of the apo $B$ in native LDL.

To determine whether $\mathrm{Lp}(\mathrm{a})$ was capable of delivering its cholesterol to cells through the LDL receptor, we compared the ability of $\mathrm{LDL}$ and $\mathrm{Lp}(\mathrm{a})$ to stimulate the incorporation of $\left[{ }^{14} \mathrm{C}\right]$ oleate into cholesteryl $\left[{ }^{14} \mathrm{C}\right]$ oleate in normal human fibroblasts. This enhancement requires receptor binding followed 


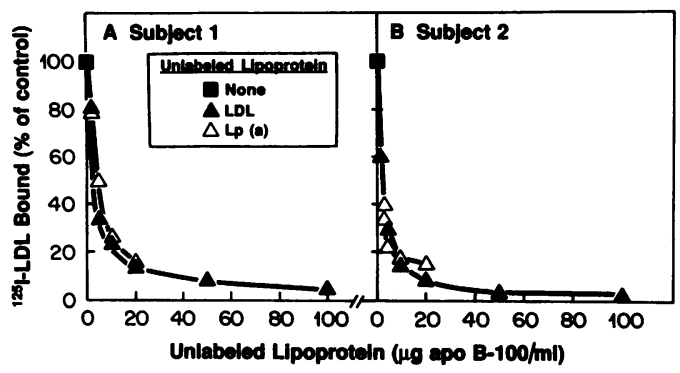

Figure 3. Competition for cell surface binding of ${ }^{125}$ I-LDL by unlabeled LDL $(\Lambda)$ and $\operatorname{Lp}(a)(\Delta)$ in transfected TR-715 hamster cells. On day $0,2 \times 10^{5}$ trypsinized cells were plated into each $22-\mathrm{mm}$ well of a 12-well plate in $2 \mathrm{ml}$ of Ham's F-12 medium supplemented with $5 \%$ (vol/vol) calf lipoprotein-deficient serum (14), $2 \mathrm{mM}$ glutamine, $100 \mathrm{U} / \mathrm{ml}$ penicillin, and $140 \mu \mathrm{g} / \mathrm{ml}$ streptomycin sulfate. On day 1 , each monolayer was chilled at $4^{\circ} \mathrm{C}$ for $30 \mathrm{~min}$ and then received 2 $\mathrm{ml}$ of ice-cold medium (14) containing 5\% lipoprotein-deficient serum, $5 \mu \mathrm{g}$ protein $/ \mathrm{ml}$ of ${ }^{125} \mathrm{I}-\mathrm{LDL}$ ( $163 \mathrm{cpm} / \mathrm{ng}$ protein), and the indicated concentration of apo B-100 in unlabeled LDL ( $(\Delta)$ or Lp(a) $(\Delta)$ from the indicated subject. After incubation for $3 \mathrm{~h}$ at $4^{\circ} \mathrm{C}$, the cells were washed and the total amount of dextran sulfate-releasable ${ }^{125} \mathrm{I}-\mathrm{LDL}$ was determined as described in Methods. Each value represents the average of duplicate incubations.

by internalization in coated pits, hydrolysis of the lipoprotein's cholesteryl esters in lysosomes, and reesterification of the cholesterol in the cytosol (20). When compared on the basis of their apo B-100 content, similar concentrations of $\mathrm{Lp}(\mathrm{a})$ did not differ in their ability to stimulate the reesterification reaction (Fig. 4).

Another available assay to test for lipoprotein binding to LDL receptors employs receptors that have been immobilized in plastic microtiter wells by binding to adsorbed antibodies

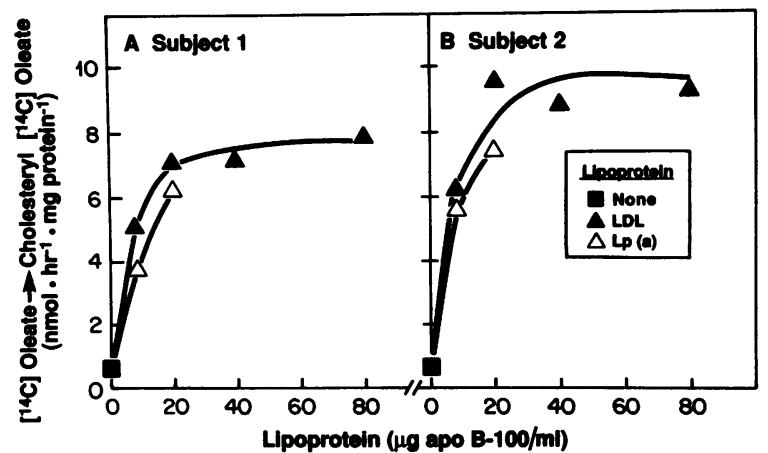

Figure 4. Lipoprotein-mediated stimulation of cholesteryl $\left[{ }^{14} \mathrm{C}\right]$ oleate formation in human fibroblasts. On day $0,2 \times 10^{4}$ trypsinized cells were plated into each 22-mm well of a 12-well plate in $2 \mathrm{ml}$ Dulbecco's modified Eagle medium containing $10 \%$ (vol/vol) fetal calf serum, $100 \mathrm{U} / \mathrm{ml}$ penicillin, and $100 \mu \mathrm{g} / \mathrm{ml}$ streptomycin sulfate. On day 1 , the medium was switched to medium containing $10 \%$ lipoprotein-deficient serum. On day 3, each monolayer received $1.2 \mathrm{ml}$ of Dulbecco's modified Eagle medium (without glutamine) containing $5 \%$ lipoprotein-deficient serum, and the indicated concentration of apo B-100 in LDL ( $\Delta)$ or $\operatorname{Lp}(a)(\Delta)$ from the indicated subject. After incubation for $5 \mathrm{~h}$ at $37^{\circ} \mathrm{C}$, the cells were pulse-labeled for $2 \mathrm{~h}$ with $0.2 \mathrm{mM}\left[{ }^{14} \mathrm{C}\right]$ oleate-albumin $(7,226 \mathrm{cpm} / \mathrm{nmol})$ and then harvested for measurment of cholesteryl $\left[{ }^{14} \mathrm{C}\right]$ oleate content. Each value is the average of duplicate incubations. directed against the receptor's COOH-terminal domain (19). Fig. 5 shows that the LDL receptor under these conditions bound ${ }^{125} \mathrm{I}-\mathrm{LDL}$ and that unlabeled LDL competed for this binding. $\mathrm{Lp}(\mathrm{a})$ from subjects 1 and 2 competed equally as well as LDL when expressed on the basis of apo B-100 content. Lp(a) from subjects 3 and 4 also competed with ${ }^{125}$ I-LDL, but the affinities appeared to be somewhat lower than that of native LDL.

To determine whether the LDL receptor is capable of removing $L p(a)$ from the circulation, we studied the catabolism of $L p(a)$ in transgenic mice that express large amounts of the human LDL receptor under control of the metallothionein-I promoter (12). Groups of normal and transgenic animals were co-injected intravenously with ${ }^{125} \mathrm{I}$-LDL and unlabeled Lp(a). After varying times, blood was drawn and examined for its content of ${ }^{125} \mathrm{I}-\mathrm{LDL}$ radioactivity and for its concentration of apo(a) as measured with a sensitive radioimmunoassay. In the normal mice, LDL and Lp(a) were removed slowly from the circulation. In the transgenic animals, the removal rate for LDL and Lp(a) were both markedly elevated $(A-D)$. The relative increase in removal rate for $L p(a)$ was similar to the relative increase in the removal rate for LDL.

Because of the overexpression of the LDL receptor in transgenic animals, plasma from these mice does not contain detectable LDL (12). To rule out the possibility that the enhanced rate of $\mathrm{Lp}(\mathrm{a})$ turnover was attributable to the low concentration of circulating LDL, we performed an additional experiment in which $\mathrm{Lp}(\mathrm{a})$ was injected together with a tracer amount of ${ }^{125} \mathrm{I}-\mathrm{LDL}$ and a large amount of unlabeled LDL that was calculated to raise the animals' LDL levels to values ap-

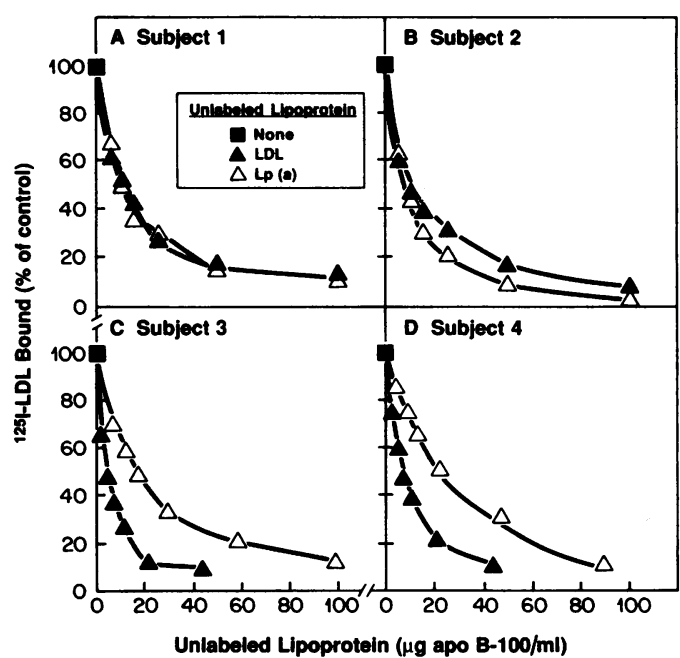

Figure 5. Competitive binding of ligands for the LDL receptor in the solid phase assay. A mouse monoclonal antibody (IgG-4A4) directed against the $\mathrm{COOH}$-terminus of the LDL receptor (19) was used to immobilize bovine LDL receptors to the bottom of microtiter wells. ${ }^{125} \mathrm{I}-\mathrm{LDL}$ ( $5 \mu \mathrm{g}$ protein $/ \mathrm{ml}$; $308-643 \mathrm{cpm} / \mathrm{ng}$ protein) alone $(\boldsymbol{a})$ or mixed with varying concentrations of apo B-100 in unlabeled LDL $(\Delta)$ or $\operatorname{Lp}(\mathrm{a})(\Delta)$ was added, and the incubation was carried out at $4^{\circ} \mathrm{C}$ for $1 \mathrm{~h}$. The wells were washed extensively with buffer (19) and counted in a gamma counter. The " $100 \%$ of control" values ranged from 1,840 to $5,360 \mathrm{cpm}$ per well. Nonspecific binding, measured in the presence of EDTA, ranged from 75 to $300 \mathrm{cpm}$ per well. Each value represents the average of duplicate determinations. 
proximating those in the control mice. We also extended the time period for the turnover study to $300 \mathrm{~min}$. As shown in panels $E$ and $F$, the ${ }^{125} \mathrm{I}-\mathrm{LDL}$ and $\mathrm{Lp}(\mathrm{a})$ were both cleared much more rapidly from the plasma of transgenic mice as compared with normal mice.

\section{Discussion}

In the current experiments, we have used five different assays to demonstrate that intact $L p(a)$ binds with high affinity to the LDL receptor. The most direct of these was the demonstration that $\mathrm{Lp}$ (a) binds to the purified receptor on nitrocellulose blots (Fig. 2). The bound $\mathrm{Lp}(\mathrm{a})$ was visualized with an antibody that was specific for the apo(a) component, ruling out the possibility that the binding was attributable to a fraction of $L p(a)$ that had lost its apo(a). In intact cells, the Lp(a) binding was functional in that it stimulated cholesterol esterification (Fig. 4), a finding that agrees with previous data of Floren et al. (7). To guard against the possibility that the activity of $\operatorname{Lp}(a)$ somehow depended on its method of purification, we used $L p(a)$ prepared in two different laboratories with two different methods, and both gave similar results.

The experiments with transgenic mice indicate that the LDL receptor can effectively remove $L p(a)$ from the circulation (Fig. 6). To make certain that we were observing the removal of intact $\mathrm{Lp}(\mathrm{a})$, we followed the $\mathrm{Lp}(\mathrm{a})$ by a radioimmunoassay that was specific for apo(a). This maneuver allowed us to avoid any modification of the $\mathrm{Lp}(\mathrm{a})$ particle, such as radioiodination or enrichment with radiolabeled lipids.

The current findings, considered together with previous data, would appear to provide a simple explanation for the elevated $\mathrm{Lp}(\mathrm{a})$ levels in FH heterozygotes that have been observed by Utermann et al. (5). If $L p(a)$ depends upon the LDL receptor for its clearance from plasma, then a reduction in LDL receptors should lead to a corresponding increase in Lp(a) levels, owing to impaired clearance. Several observations argue against such a simple interpretation, however.

First, although a defect in LDL receptors raises $L p(a)$ levels (5), a mutation in apo B-100 that abolishes receptor binding $(21,22)$ does not elevate $\operatorname{Lp}(\mathrm{a})$ levels (1). Theoretically, if $\mathrm{Lp}(\mathrm{a})$ removal is dependent upon apo B-100 binding to LDL receptors, then the apo(a) should accumulate together with its defective apo B-100 in the blood. Second, drugs that increase LDL receptor activity, such as bile acid-binding resins and 3-hydroxy-3-methylglutaryl CoA reductase inhibitors, do not appear to lower $\mathrm{Lp}(\mathrm{a})$ levels in plasma (1). Third, the clearance of $L p(a)$ from blood was less markedly reduced than the clearance of LDL in one FH homozygote studied by Krempler et al. (10). Fourth, the variation in $L p(a)$ levels among individuals appears to be caused by differences in the rate of synthesis of $L p(a)$ rather than in its rate of degradation (10). The latter studies were performed before it was realized that the different alleles at the apo(a) locus produce different levels of apo(a) in plasma, owing to differences in production rate (1).

At present, there is no simple way to reconcile all of these data. What is needed is a comparative study of $L p(a)$ turnover in individuals with different genotypes at the apo(a) locus and the LDL receptor locus. It will also be necessary to determine carefully whether $\mathrm{Lp}$ (a) particles produced by different alleles at the apo(a) locus bind with equal affinity to LDL receptors. The current study does not include a sufficient number of patients to begin to make any such correlation. If such studies

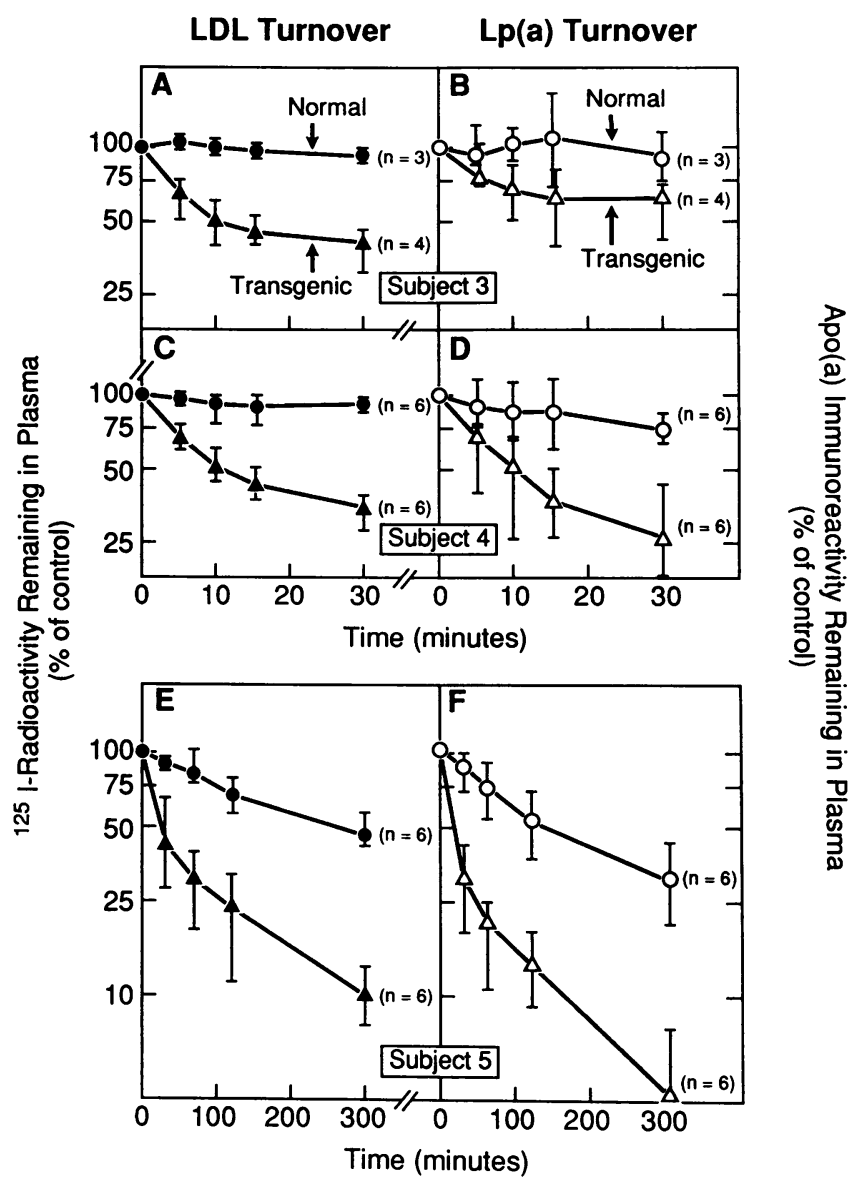

Figure 6. Clearance of ${ }^{125} \mathrm{I}-\mathrm{LDL}$ and unlabeled $\mathrm{Lp}(\mathrm{a})$ from the plasma of normal and transgenic mice that overexpress the human LDL receptor. Data from three separate experiments using different $\mathrm{Lp}(\mathrm{a})$ preparations from the indicated subject are shown. Normal mice $(\bullet, 0)$ and transgenic mice $(\Delta, \Delta)$ were injected intravenously with a mixture of ${ }^{125} \mathrm{I}-\mathrm{LDL}$ ( $5 \mu \mathrm{g}$ protein, $400-440 \mathrm{cpm} / \mathrm{ng}$ protein) and unlabeled $\mathrm{Lp}$ (a) (2-6 $\mu \mathrm{g}$ of total protein), and blood was collected at the indicated times for determination of ${ }^{125} I$ content $(\bullet, \Delta)$ by gamma counting and $L p(a)$ content $(O, \Delta)$ by immunoassay. The " $100 \%$ of control" values represents the values for plasma ${ }^{125}$ I and $\mathrm{Lp}(\mathrm{a})$ at $1 \mathrm{~min}$ after injection in each animal. The mean and range of values for the indicated number of animals are shown. In $E$ and $F$, excess unlabeled LDL ( $0.5 \mathrm{mg}$ protein) was included in the injection mixture for the transgenic mice only. The mean value of plasma apo B in the normal mice was $39 \pm 7.4 \mathrm{mg} / \mathrm{dl}$ (SD) before injection and $37 \pm 9.3 \mathrm{mg} / \mathrm{dl}$ at $1 \mathrm{~min}$ after injection; the mean value in the transgenic mice was 0 before injection and $30 \pm 9.5 \mathrm{mg} / \mathrm{dl}$ at $1 \mathrm{~min}$ after injection. The source of $\operatorname{Lp}(a)$ in these experiments was as follows: $A$ and $B$, subject $3 ; C$ and $D$, subject $4 ; E$ and $F$, subject 5 .

are performed with ${ }^{125} \mathrm{I}$-labeled $\mathrm{Lp}(\mathrm{a})$, it will be necessary to demonstrate that the ${ }^{125} \mathrm{I}-\mathrm{Lp}(\mathrm{a})$ is biologically active in binding to $\mathrm{LDL}$ receptors. Under some conditions, radioiodination might inactivate the binding properties of $\mathrm{Lp}(\mathrm{a})$, and this must be avoided. It should be noted that all of the studies performed in this paper were done with unlabeled $\mathrm{Lp}(\mathrm{a})$.

In addition, it will be necessary to learn how $L p(a)$ is produced. Does the apo(a) protein ever exist on a precursor of LDL such as intermediate density lipoprotein (IDL)? If such $\mathrm{Lp}$ (a)-bearing precursors exist, do they retain their customary high affinity for binding to LDL receptors? It will also be cru- 
cial to determine whether apo(a) is added to LDL in the liver during secretion, or whether the attachment occurs after very low density lipoprotein has been partially or completely metabolized to IDL and LDL. The latter event occurs in the liver under the influence of hepatic lipase (23), and it is possible that the apo(a) is not attached to apo B-100 until this stage of metabolism has been reached. Variations in the rate of IDL lipolysis might therefore modulate $\mathrm{Lp}$ (a) levels. Clearly, additional work will be required before our understanding of the relationship between $L p(a)$ and $L D L$ receptors is complete.

\section{Acknowledgments}

We thank John Kane (University of California, San Francisco) for referral of patients with elevated Lp(a) levels, Wai Lee T. Wong and Philip E. Hass for performing immunoassays of $L p(a)$, and Sharon Tucker and Shanna Maika for excellent technical assistance.

This work was supported by research grants from the National Institutes of Health (HL-20948), the Perot Family Foundation, and the Moss Heart Foundation. Dr. Hofmann is the recipient of an American Heart Association/Squibb Clinician Scientist Award 86-412.

\section{References}

1. Utermann, G. 1990. The mysteries of $L p(a)$ lipoprotein. Science (Wash. DC). 246:904-910.

2. McLean, J. W., J. E. Tomlinson, W.-J. Kuang, D. L. Eaton, E. Y. Chen, G. M. Fless, A. M. Scanu, and R. M. Lawn. 1987. cDNA sequence of human apolipoprotein(a) is homologous to plasminogen. Nature (Lond.). 300:132-137.

3. Brown, M. S., and J. L. Goldstein. 1987. Plasma lipoproteins: teaching old dogmas new tricks. Nature (Lond.). 330:113-114.

4. Utermann, G., H. J. Menzel, H. G. Kraft, H. C. Duba, H. G. Kemmler, and C. Seitz. 1987. Lp(a) glycoprotein phenotypes. Inheritance and relation to $\mathrm{Lp}(\mathrm{a})$-lipoprotein concentrations in plasma. $J$. Clin. Invest. 80:458-465.

5. Utermann, G., F. Hoppichler, H. Dieplinger, M. Seed, G. Thompson, and E. Boerwinkle. 1989. Defects in the low density lipoprotein receptor gene affect lipoprotein (a) levels: multiplicative interaction of two gene loci associated with premature atherosclerosis. Proc. Natl. Acad. Sci. USA. 86:4171-4174.

6. Maartmann-Moe, K., and K. Berg. 1981. Lp(a) lipoprotein enters cultured fibroblasts independently of the plasma membrane low density lipoprotein receptor. Clin. Genet. 20:352-362.

7. Floren, C.-H., J. J. Albers, and E. L. Bierman. 1981. Uptake of Lp(a) lipoprotein by cultured fibroblasts. Biochem. Biophys. Res. Commun. 102:636-639.

8. Havekes, L., B. J. Vermeer, T. Brugman, and J. Emeis. 1981. Binding of $\mathrm{Lp}(\mathrm{a})$ to the low density lipoprotein receptor of human fibroblasts. FEBS (Fed. Eur. Biochem. Soc.) Lett. 132:169-173.

9. Armstrong, V. W., A. K. Walli, and D. Seidel. 1985. Isolation, characterization, and uptake in human fibroblasts of an apo(a)-free lipoprotein obtained on reduction of lipoprotein(a). J. Lipid Res. 26:1314-1323.

10. Krempler, F., G. M. Kostner, A. Roscher, F. Haslauer, K. Bolzano, and F. Sandhofer. 1983. Studies on the role of specific cell surface receptors in the removal of lipoprotein (a) in man. J. Clin. Invest. 71:1431-1441.

11. Schneider, W. J., J. L. Goldstein, and M. S. Brown. 1985 Purification of the LDL receptor. Methods Enzymol. 109:405-417.

12. Hofmann, S. L., D. W. Russell, M. S. Brown, J. L. Goldstein, and R. E. Hammer. 1988. Overexpression of low density lipoprotein (LDL) receptor eliminates LDL from plasma in transgenic mice. Science (Wash. DC). 239:1277-1281.

13. Beisiegel, U., W. J. Schneider, M. S. Brown, and J. L. Goldstein. 1982. Immunoblot analysis of low density lipoprotein receptors in fibroblasts from subjects with familial hypercholesterolemia. J. Biol. Chem. 257:13150-13156.

14. Goldstein, J. L., S. K. Basu, and M. S. Brown. 1983. Receptormediated endocytosis of LDL in cultured cells. Methods Enzymol. 98:241-260.

15. Ye, S. Q., V. N. Trieu, D. L. Stiers, and W. J. McConathy. 1988. Interactions of low density lipoprotein ${ }_{2}$ and other apolipoprotein B-containing lipoproteins with lipoprotein(a). J. Biol. Chem. 263:6337-6343.

16. Wong, W. T., D. Eaton, A. Berloui, B. Fendly, and P. Hass. 1990. A monoclonal-based ELISA for Lp(a). Clin. Chem. 36:192-197.

17. Davis, C. G., A. Elhammer, D. W. Russell, W. J. Schneider, S. Kornfeld, M. S. Brown, and J. L. Goldstein. 1986. Deletion of clustered O-linked carbohydrates does not impair function of low density lipoprotein receptor in transfected fibroblasts. J. Biol. Chem 261:2828-2838.

18. Daniel, T. O., W. J. Schneider, J. L. Goldstein, and M. S. Brown. 1983. Visualization of lipoprotein receptors by ligand blotting. J. Biol. Chem. 258:4606-4611.

19. van Driel, I. R., M. S. Brown, and J. L. Goldstein. 1989. Stoichiometric binding of low density lipoprotein (LDL) and monoclonal antibodies to LDL receptors in a solid phase assay. J. Biol. Chem. 264:9533-9538.

20. Goldstein, J. L., S. E. Dana, and M. S. Brown. 1974. Esterification of low density lipoprotein cholesterol in human fibroblasts and its absence in homozygous familial hypercholesterolemia. Proc. Natl. Acad. Sci. USA. 71:4288-4292.

21. Innerarity, T. L., K. H. Weisgraber, K. S. Arnold, R. W. Mahley, R. M. Krauss, G. L. Vega, and S. M. Grundy. 1987. Familial defective apolipoprotein B-100: Low density lipoproteins with abnormal receptor binding. Proc. Natl. Acad. Sci. USA. 84:6919-6923.

22. Soria, L. F., E. H. Ludwig, H. R. G. Clarke, G. L. Vega, S. M. Grundy, and B. J. McCarthy. 1989. Association between a specific apolipoprotein B mutation and familial defective apolipoprotein B-100. Proc. Natl. Acad. Sci. USA. 86:587-591.

23. Jackson, R. L. 1984. Lipoprotein lipase and hepatic lipase. In The Enzymes. P. D. Boyer, editor. Academic Press, New York. 141-181.

24. Laemmli, U. K. 1970. Cleavage of structural proteins during the assembly of the head of bacteriophage T4. Nature (Lond.). 227:680-685. 